\title{
EKSISTENSI PLTMH CINTA MEKAR DALAM PEMBERDAYAAN MASYARAKAT MELALUI KOPERASI MEKAR SARI DI DESA CINTA MEKAR KECAMATAN SERANG PANJANG KABUPATEN SUBANG PROVINSI JAWA BARAT
}

\author{
Eko Ariyanto, Iman Setiono, Priyo Sasmoko, Zaka Adi Pamungkas \\ Program Studi Diploma III Teknik Elektro \\ Sekolah Vokasi Universitas Diponegoro
}

\begin{abstract}
Eko Ariyanto, Iman Setiono, Priyo Sasmoko, Zaka Adi Pamungkas, in this paper explain that PLTMH located in CintaMekar Village, SerangPanjang Sub-District, Subang Province, West Java Province, utilizes Ciasem River water, processed so that it has high water fall 17,61 m, water discharge design 1,100 l/s, hydraulic potential of $160 \mathrm{KW}$, turbine efficiency of 0.73, efficiency of generator 0.89 , out put generator 120 $\mathrm{KW}$, loses $4 \mathrm{KW}$ and total electrical energy generated $116 \mathrm{KW}$. The purpose of development, to help people who were not reached PLN electricity, to empower the community.Empowerment begun from the time of development, where citizens are involved, which then able to become operators. The result of energy from PLTMH is sold to PLN, then the result is reduced for operational costing, maintenance cost, import cost / electricity payment used, depreciation cost of equipment taken from $10 \%$ of transactions, divided by two $(50 \%$ for PT HidropirantiIntiBaktiSadaya, as shareholder) and 50\% for Mekar Sari Cooperative, used for community empowerment. Since its operation, people who do not have electricity grid, are connected to electricity. In addition, the proceeds from the sale of electricity to PLN are used to help with the cost of education / scholarship, health, loans for business and cooperative operations. Empowerment implemented or managed Mekar Sari Cooperative. Along with the development of the era, empowerment assistance now being implemented includes: Health Sector in cooperation with Village Midwife, Savings and Loans and Scholarships for Primary School - 10 People and Junior High School - 5 People.
\end{abstract}

Keywords: Potential Water Resources, New and Renewable Energy Power, PLTMH Cinta Mekar, Mekar Sari Cooperative, Community Empowerment

\section{PENDAHULUAN}

Energi listrik senantiasa menjadi kebutuhan pokok dan memainkan peranan penting dalam kehidupan manusia. Apalagi penyediaan energi listrik yang memadai dan murah serta ramah lingkungan, tentunya merupakan salah satu persyaratan untuk mendukung pembangunan sosial ekonomi berkelanjutan. Sebagaimana sering disampaikan pemerintah, tujuan pembangunan ketenagalistrikan adalah untuk menjamin ketersediaan tenaga listrik dalam jumlah yang cukup, kualitas yang baik dan harga yang wajar, dalam rangka meningkatkan kesejahteraan dan kemakmuran rakyat secara adil dan merata serta mewujudkan pembangunan berkelanjutan.

Upaya ke sana, diantaranya dengan memanfaatkan sumber energi primer, sesuai dengan Kebijakan Energi Nasional untuk menjamin penyediaan tenaga listrik yang berkelanjutan. Namun kenyataan yang ada, keterbatasan ketersediaan energi listrik merupakan salah satu hambatan dalam pembangunan dan pengembangan masyarakat pedesaan. Menurut data dari Kementerian Energi dan Sumber Daya Mineral, untuk tahun 2015, rasio elektrifikasi Indonesia baru mencapai86,39 \%. Ini berarti kapasitas terpasang saat ini baru dapat memenuhi kebutuhan listrik sebesar $86,39 \%$.
Sementara menurut Brosur Energi Listrik Ramah Lingkungan Untuk Rakyat, kerja sama MKI (Masyarakat Ketenaga-listrikan Indonesia), Ibeka (Institut Bisnis dan Ekonomi Kerakyatan), PLN (Perusahaan Listrik Negara), masih cukup banyak warga masyarakat yang belum terjangkau tenaga listrik, sehingga belum dapat menikmati energi listrik, sebagaimana anak bangsa lainnya yang sudah menikmatinya, baik karena keterbatasan infrastruktur maupun kapasitas listrik yang tersedia.Program 35.000 MWdi tahun 2015 - 2019, diharapkan akan membuat perkembangan rasio di tiap tahunnya. Target tahun $2016: 91,3 \% ; 2017$ : 93,6\%; 2018 : 95,8 \% dan tahun 2019 mencapai $97,4 \%$.

Pemilihan sumber energi alternatif yang ramah lingkungan yang tak meninimbulkan polusi yang sampai saat ini masih belum dimanfaatkan secara optimal adalah tenaga air. Potensitenaga air di Indonesia sebesar $75.000 \mathrm{MW}$, baru 2,5\% termanfaatkan, yang sebagian besar merupakan pembangkit listrik tenaga air (PLTA). Alternatif pemanfaatan tenaga air yang belum populer di Indonesia dan berpotensi untuk dikembangkan adalah pembangkit listrik tenaga air skala kecil, atau lebih populer dengan sebutan Minihidro dan Mikrohidro.

Salah satu pembangkit listrik skala kecil yang potensial dan dirasakan manfaat keberadaannya oleh 
warga masyarakat setempat adalah pembangkit Listrik Tenaga Mikro Hidro (PLTMH) Cinta Mekar, yang ada di Desa Cinta Mekar Kecamatan Serang Panjang Kabupaten Subang Propinsi Jawa Barat. Di PLTMH ini diselenggarakan pemberdayaan bagi masyarakat, mencakup antara lain dalam mengoperasikan PLTMH, untuk biaya pendidikan, pembangunan infra struktur desa, peningkatan kesejahteraan warga/ekonomi warga lewat usaha produktif.

Inilah yang dilakukan dalam penelitian di PLTMH Cinta Mekar, di mana hasil energi dari PLTMH tersebut, $50 \%$ nya (usai dikurangi biaya operasi dan perawatan) dipergunakan untuk pemberdayaan masyarakat setempat, melalui Koperasi Mekar Sari 50 \%, lainnya menjadi hak dari PT. Hidro Piranti, sebagai investor dalam pembangunannya.

Sejak awal masyarakat Cinta Mekar dilibatkan dalam pembangunan PLTMH berkapasitas daya maksimal 120 kilowatt tersebut. Yayasan Ibeka mendampingi dalam kegiatan sosialkemasyarakatannya. Tim sosial Ibeka melakukan persiapan-persiapan mulai dari pencatatan data awal, pembentukan organisiasi, pembentukan kapasitas dan kepemilikan."PLTMH berbasis masyarakat selain secara teknis harus well designed, ia juga harus memiliki nilai tambah dan yang terpenting juga well maintained. Suksesnya PLTMH juga didukung oleh faktor kemampuan organisasi dan lembaga lokal serta kemanfaatan dari nilai tambah PLTMH tersebut," terang Ir. Iskandar Budi Saroso, staf ahli Ibeka.

Sistem PLTMH berbasis masyarakat inilah yang menjadi kunci keberhasilan megaproyek swadaya listrik Cinta Mekar. Penduduk terjun langsung dalam mengelola seluruh perawatan, pengorganisasisan, hingga pola penagihan terhadap pelanggan.

Sementara menurut Yan Sophian, operator pembangkit listrik, desa ini dulunya terbelakang, terutama dari sisi pendidikan dan ekonomi. Tapi berkat usaha dua perusahan piranti hidro PT IBEKA dan PT HIBS, proyek pembangkit listrik tingkat desa ini akhirnya terwujud. Dengan bantuan dana dari badan PBB yang mengurusi Ekonomi dan Sosial untuk Asia Pasific (UNESCAP), pada 2003 proyek ini mulai dibangun. "Setelah rampung, dibangunlah koperasi guna menunjang operasional pembangkit itu," jelas Yan Sophian.

Menurut Yuyun Yuningsih, Ketua Koperasi Mekar Sari, hasil penjualan listrik ke PLN ini dikembalikan lagi ke warga. Bentuknya bisa berupa bantuan pemasangan instalasi listrik (dahulu sebelum semua warga memiliki isntalasi listrik di rumahnya, namun sesuai dengan perkembangan yang ada, semua warga rumahnya telah dialiri listrik, maka dana untuk keperluan tersebut dialihkan ke kegiatan lainnya), dana pendidikan, juga dana kesehatan. Untuk kesehatan, koperasi membantu Rp
100 ribu kepada warga yang melahirkan atau yang sedang sakit.

Sementara menurut Menteri Energi dan Sumber Daya Mnineral Poernomo Yusgiantoro, pembangunan pembangkit listrik tenaga mikrohidro, sesuai dengan apa yang telah diamanatkan dalam UU Kelistrikan. Pernyataan ini disampaikan Poerrnomo saat meresmikan PLTMH Cinta Mekar dengan kapasitas 120 kilowatt (KW) di Desa Cinta Mekar, Kecamatan Sagala Herang (dahulu, sekarang masuk ke Kecamatan Serang Panjang - peneliti), Kabupaten Subang, Jawa Barat.

\section{TINJAUAN PUSTAKA}

PLTMH adalah pembangkit listrik yang menggunakan tenaga air sebagai media utama untuk menggerakkan turbin yang selanjutnya menggerakkan generator. Tenaga mikrohidro dengan skala daya yang dapat dibangkitkan hingga 200 KW. Pada PLTMH proses perubahan energy kinetic berupa kecepatan dan tekanan air, yang digunakan untuk menggerakkan turbin air dan generator listrik hingga menghasilkan energi listrik (Noto Sudjono, D, 2002).

Pengertian potensi di sini adalah gambaran besaran kapasitas pembangkit listrik yang mungkin dapat dikembangkan di suatu rencana lokasi tertentu. Sesuai dengan sifat dasar dan proses / mekanisme dari terbangkitkannya energi listrik yang bersumber dari tenaga air, ada dua komponen utama yang menjadi dasar dari terjadinya proses pembangkitan tersebut, yaitu debit air dan tinggi jatuh air (head).

Energi dari tenaga air ini merupakan energi potensial, maka besaran kapasitas / potensi juga dipengaruhi oleh percepatan gravitasi. Dengan demikian potensi tenaga air atau kapasitas pembangkit dapat diperkirakan dari rumus sebagai berikut :

keterangan :

$$
\mathrm{P}=\eta \mathrm{gqh}
$$

$\mathrm{P} \quad$ : kapasitas daya pembangkit

$\eta \quad$ : efisiensi peralatan elektromekanik (E/M)

g : percepatan gravitasi

$\mathrm{q}:$ debit air

h : tinggi jatuh

Efisiensi peralatan E/M di sini adalah efisiensi gabungan dari efisiensi turbin dan generator. Dengan demikian akan mudah kita dapat memperkirakan kapasitas daya pembangkit di suatu lokasi rencana PLTMH dengan hanya mengetahui variabel debit air dan tingginya jatuh (head). Besaran $\eta \mathrm{g}$ dapat didekati dengan perkiraan gravitasi $\mathrm{g}=9,8 \mathrm{~m} / \mathrm{det}^{2}$. Biasanya $\eta \mathrm{g}$ diberi harga pendekatan 7,5. Jadi rumus perkiraan di atas menjadi :

$$
\mathrm{P}=7,5 \mathrm{q} \mathrm{h}
$$

Apa yang telah diuraikan di atas merupakan langkah-langkah baku dalam pengembangan PLTMH. Sedang untuk PLTMH berkapasitas sekitar 
$200 \mathrm{~kW}$, acuan yang dipakai adalah satuan areal atau wilayah luasan tertentu (misal kecamatan, desa, dsb). Sasarannya adalah untuk menentukan areal tertentu yang mempunyai kecenderungan untuk ditemukannya lokasi rencana PLTMH, yang direpresentasikan dalam 2 (dua) variabel yang mewakili debit dan head.

Variabel debit diwakili oleh jumlah rata-rata bulan kering dalam satu tahun. Dengan jumlah bulan kering yang kecil atau tidak ada, akan terjamin bahwa areal tersebut cukup "basah" atau cukup terseda aliran.

Variabel head diwakili oleh kemiringan atau gradien rata-rata secara skematik (non fisik).

Dengan mengetahui tingkat kemiringan yang diwakili oleh indikator gradien skematik, semakin miring areal (angka gradien membesar), semakin besar kemungkinan untuk ditemukannya head yang cukup untuk PLTMH. Gradien skematik rata-rata dirumuskan sebagai berikut :

keterangan :

$$
\mathrm{I}=\mathrm{h}-\mathrm{h}
$$

h1 : elevasi titik tertinggi

h2 : elevasi titik terendah

A : luasareal (kecamatan, desa, dsb)

\section{PEMBERDAYAAN MASYARAKAT}

Pemberdayaan masyarakat yang ada terkait dengan eksistensi PLTMH Cinta Mekar melalui Koperasi Mekar Sari, antara lain terlihat dengan diajak turut sertanya warga masyarakat setempat dalam mengoperasikan pembangkit tenaga mikrohidro ini, di samping perawatannya, pengelolaannya.

Pemberdayaan yang ada dari hasil energi PLTMH Cinta Mekar, melalui Koperasi Mekar Sari dipergunakan untuk pemberdayaan masyarakat berupa bantuan biaya pendidikan berupa bea siswa, kesehatan, bantuan modal usaha. Tentunya meliputi pula biaya operasional koperasi, gaji karyawan.

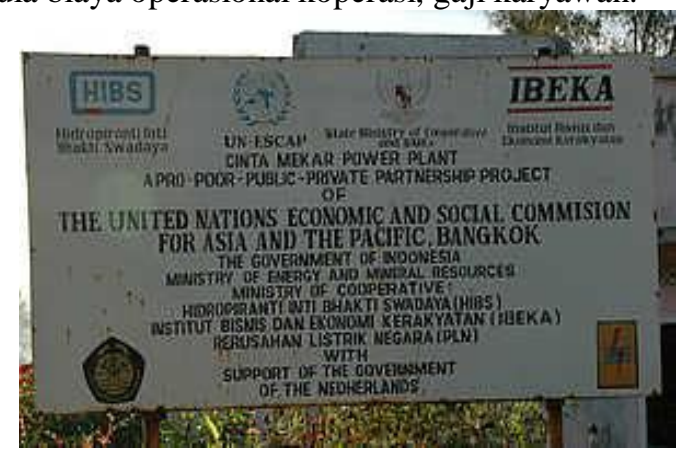

Gambar 1. Papan Nama PLTMH Cinta Mekar

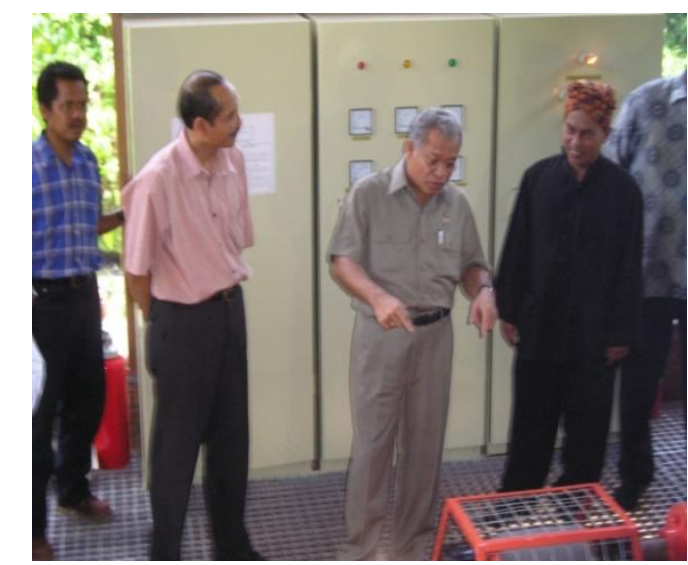

Gambar 2. Menteri ESDM, Poernomo Yusgiantoro, saat mengadakan peninjauan di PLTMH Cinta

Mekar, usai meresmikannya

\section{METODOLOGI PENELITIAN}

Lokasi penelitian dilaksanakan di PLTMH Cinta Mekar dan Koperasi Mekar Sari, yang ada di Desa Cinta Mekar Kecamatan Serang Panjang Kabupaten Subang Propinsi Jawa Barat. Lama waktu penelitian selama 6 (enam) bulan, sejak Maret 2016 s/d Agustus 2016, dimulai survei lapangan hingga laporan akhir. Dalam laporan ini, penelitian yang dilakukan dalam konteks waktu operasional PLTMH Cinta Mekar selama Tahun 2014 (Januari Desember 2014).

Ruang lingkup potensi yang ada, kapasitas energi yang dihasilkan, data kependudukan. Pembangkit Listrik Tenaga Mikro Hidro di Cinta Mekar-Subang, merupakan PLTMH jenis run off river dengan debit run off sebesar $1,5 \mathrm{~m}^{3} /$ detik melalui 2 pipa pesat dengan diameter penstock 0,58, tinggi jatuhan ( head ) 18 meter. Estimasi output daya generator 100,356 kW.

Metode penelitian melalui indepth interview dan survey, analisa data yang digunakan penelitian menerapkan kaidah penelitian kualitatif, dengan cara mengumpulkan, mengklasifikasikan data, menafsirkan data, membuat kesimpulan dari data.

Model Operasi di PLTMH Cinta Mekar, Sungai Ciasem dibendung, debit airnya yang 1.500 $\mathrm{m} /$ detik, sebanyak $1.100 \mathrm{~m} /$ detik dibelokkan ke saluran run-off sepanjang $400 \mathrm{~m}$ menuju bak penenang, lantas ke bak pengendap, masuk ke pipa pesat yang berjumlah dua buah, masing-masing berdiameter $0,53 \mathrm{~m}$ dan dijatuhkan ke turbin (Crossflor Twin Turbine T-13) dengan tinggi jatuh air $18 \mathrm{~m}$, menekan sudu-sudu dalam turbin kembar. Turbin dikopel dengan generator listrik sinkron berkapasitas $160 \mathrm{kVA}$, membangkitkan energi listrik dengan daya maksimal $120 \mathrm{~kW}$, kemudian air tadi kembali ke Sungai Ciasem. Out put energi listrik dari generator lantas ke trafo step up, baru disalurkan ke JTM PLN yang berjarak $150 \mathrm{~m}$.

Perkiraan Kapasitas PLTMH Cinta Mekar, Kabupaten Subang Provinsi Jawa Barat 
Tabel 1. Perkiraan kapasitas PLTMH Cinta Mekar

\begin{tabular}{lll}
\hline Item & Unit & Jumlah \\
\hline -Perkiraan tinggi jatuh & $\mathrm{Hgl}$ & $18 \mathrm{~m}$ \\
-Pemecahan terukur & $\mathrm{Qm}$ & $1500 \mathrm{l} / \mathrm{s}$ \\
pada hulu saluran irigasi & & \\
-Pemecahan desain & $\mathrm{Qd}$ & $1100 \mathrm{l} / \mathrm{s}$ \\
-Potensi tenaga hidrolik & $\mathrm{Ph}$ & $160 \mathrm{~kW}$ \\
$\begin{array}{l}\text {-Perkiraan bersih tinggi } \\
\text { jatuh }\end{array}$ & $\mathrm{Hnet}$ & $17,61 \mathrm{~m}$ \\
$\begin{array}{l}\text {-Perkiraan efisiensi turbin } \\
\text {-Perkiraan efisiensi gen }\end{array}$ & $\mathrm{T} 1$ & 0,73 \\
$\begin{array}{l}\text {-Perkiraan daya listrik gen } \\
\text { pada sumber daya }\end{array}$ & Pel 12 & 0,89 \\
$\begin{array}{l}\text {-Perkiraan rugi2 trafo,2 \% } \\
\text {-Perkiraan total daya }\end{array}$ & Ploss 1 & $4 \mathrm{~kW}$ \\
$\begin{array}{l}\text { listrik yang dikirim ke } \\
\text { jaringan PLN }\end{array}$ & Peltot & $116 \mathrm{~kW}$ \\
\hline
\end{tabular}

Model pemeliharaan, dilakukan operator dari warga masyarakat setempat, yang dididik dan dilatih pihak Ibeka, sehingga berkemampuan mengoperasikan dan memelihara PLTMH.

Model pengelolaan PLTMH Cinta Mekar dalam manajemen dikelola Koperasi Mekar Sari. Out put energi listrik dijual ke PLN, selanjutnya Koperasi Mekar Sari mengajukan tagihan ke APJ PLN Subang.

\section{HASIL DAN PEMBAHASAN}

Saat dilaksanakan penelitian yang dimulai Bulan Maret 2016 hingga Juli 2016, ternyata dana yang diperoleh Koperasi Mekar Sari terkait out put energi listrik PLTMH Cinta Mekar yang dijual ke PLN, dimulai saat awal operasi hingga Tahun 2014, ternyata mengalami pasang surut. Saat dua turbin yang ada dapat berjalan seiring untuk menggerakkan generator, hasil yang diperoleh cukup besar, sesuai rencana. Namun seiring berjalannya waktu, terjadi kondisi yang agak berbeda, di mana turbin yang sehat cuma satu, bahkan sering bergantian dalam opersionalnya, sehingga out put energi PLTMH Cinta Mekar yang dijual ke PLN pun mengalami penurunan. Hal ini membawa dampak dana yang diperoleh Koperasi Mekar Sari pun mengalami penurunan. Semula energi yang dijual ke PLN, menghasilkan dana Rp 31,2 juta per bulan. Jumlah ini didapat dari rata-rata produksi $100 \mathrm{KW}$ x 24 jam x 25 hari x Rp 520,-. Dikurangi depresiasi, biaya operasi dan pemeliharaan ( $60 \%$ dari pemasukan) Rp 18,72 juta, keuntungan bersih Rp 12,48 juta, 50 $\%$ untuk PT. HIBS dan $50 \%$ untuk Koperasi Mekar Sari, masing-masing Rp 6,24 juta.

Sebelum ditampilkan hasil penelitian terkait dana hasil penagihan ke PLN di Bulan Januari 2014 - Desember 2014 (Tabel 3), lengkap dengan biaya operasional, biaya perawatan dan biaya lainnya, berikut akan ditampilkan lebih dahulu secara sederhana data hasil penagihan dari PLN di Bulan Juni2004 dan seterusnya hingga Desember 2010, Bulan Oktober 2012 - Desember 2013 (Tabel 2). Bersama data tersebut akan terlihatdana yang diperoleh Koperasi Mekar Sari yang selanjutnya dipergunakan untuk pemberdayaan masyarakat. Dari sini akan bisa terungkap adanya pasang surut dana yang diperoleh Koperasi Mekar Sari, hal ini tentu terkait dengan hasil output energi listrik PLTMH Cinta Mekar yang dijual ke PLN.

Tabel 2. Dana Penagihan dan Hasil Transaksi Yang Diterima Koperasi Mekar Sari

\begin{tabular}{llll}
\hline No. & BulanPenagihan & Jumlah Penagihan & Terima Bersih Koperasi \\
\hline 1. & Juni - Oktober 2004 & 34.318 .080 & 5.000 .000 \\
2. & November 2004 - Februari 2005 & 27.768 .960 & 2.482 .672 \\
3. & Maret - Mei 2005 & 39.317 .184 & 3.248 .788 \\
4. & Juni - Agustus 2005 & 69.686 .784 & 5.526 .508 \\
5. & September - November 2005 & 55.066 .176 & 4.429 .963 \\
6. & Desember 2005 - April 2006 & 44.319744 & 3.823 .980 \\
7. & Mei - Agustus 2006 & 64.665 .246 & 5.249 .893 \\
8. & September - Oktober 2006 & 22.286 .016 & 1.871 .451 \\
9. & November - Desember 2006 & 15.142 .464 & 1.335 .684 \\
10. & Januari - Februari 2007 & 18.805 .824 & 1.610 .436 \\
11. & Maret - April 2007 & 46.438 .272 & 3.682 .870 \\
12. & Mei 2007 & 12.892 .608 & 1.066 .945 \\
13. & Juni 2007 & 12.222 .144 & 1.016 .660 \\
14. & Juli 2007 & 13.248 .576 & 1.093 .643 \\
15. & Agustus - September 2007 & 24.931 .584 & 2.069 .868 \\
16. & Oktober - November 2007 & 22.317 .120 & 3.012 .371 \\
17. & Desember 2007 - Januari 2008 & 42.170 .112 & 8.634 .022 \\
18. & Februari 2008 - April 2008 & 67.210 .560 & 13.742 .112 \\
19. & Mei - Juni 2008 & 26.925 .696 & 5.585 .139 \\
20. & Juli - Agustus 2008 & 25.379 .136 & 5.275 .827 \\
21. & September - Oktober 2008 & 23.219 .136 & 4.843 .827 \\
22. & November - Desember 2008 & 18.636 .480 & 3.927 .296 \\
\hline
\end{tabular}




\begin{tabular}{llll}
\hline 23. & Januari - September 2009 & 54.394 .752 & 11.778 .950 \\
24. & Oktober 2009- Januari 2010 & 41.479 .360 & 8.695 .872 \\
25. & Februari - Mei 2010 & 52.755 .040 & 10.951 .008 \\
26. & Juni - Oktober 2010 & 31.160 .480 & 6.732 .096 \\
27. & November - Desember 2010 & 22.626 .240 & 4.725 .248 \\
28. & Oktober 2012 & 7.644 .000 & 1.269 .600 \\
29. & November 2012 & 12.507 .040 & 3.193 .816 \\
30. & Desember 2012 & 5.295 .580 & 105.272 \\
31. & Januari 2013 & 1.262 .560 & 1.651 .576 \\
32. & Februari 2013 & 9.006 .400 & 1.718 .560 \\
33. & Maret 2013 & 12.205 .440 & 3.019 .176 \\
34. & April 2013 & 9.501 .440 & 1.355 .276 \\
35. & Mei 2013 & 12.016 .160 & 2.457 .264 \\
36. & Juni 2013 & 14.899 .040 & 3.644 .516 \\
37. & Juli 2013 & 7.852 .000 & 612.400 \\
38. & Agustus 2013 & 11.204 .960 & 2.071 .584 \\
39. & September 2013 & 12.101 .440 & 2.497 .776 \\
40. & Oktober 2013 & 12.051 .520 & 2.471 .608 \\
41. & November 2013 & 12.228 .320 & 2.529 .128 \\
42. & Desember 2013 & 5.566 .080 & 317.268 \\
\hline
\end{tabular}

Tabel 3. Pemanfaatan dana untuk pemberdayaan masyarakat

\begin{tabular}{lllll}
\hline No & $\begin{array}{l}\text { Dana Yang } \\
\text { Diterima }\end{array}$ & Bea Siswa & Kesehatan & $\begin{array}{l}\text { Modal } \\
\text { Simpan } \\
\text { Pinjam }\end{array}$ \\
\hline 1. & Rp 19. 536.944,- & SD : & Rp 1, 5 juta & Rp 70 juta \\
& & & \\
& & & \\
& & Rp 3.600.000,- & \\
& & & \\
& & $60.000 \times 5 \times 10$ & \\
& $=R p 3.600 .000,-$ & & \\
& & & \\
& & & \\
& & & \\
& & & \\
\hline
\end{tabular}

\section{KESIMPULAN}

- Dana hasil penjualan ke PLN yang kemudian dikelola Koperasi Mekar Sari, untuk Tahun 2014, mencapai Rp 19.536.944,-, dipergunakan untuk pemberdayaan masyarakat dalam wujud :

- Bantuan Kesehatan bekerja sama dengan Bidan Desa, besar bantuan Rp 10.000,- s/d Rp 15.000,-. Berjumlah Rp 1,5 juta. Dana bea siswa untuk 10 anak SD, besar bea siswa Rp 30.000 / anak / bulan, total di Tahun $2014=$ Rp 3,6 juta. Untuk 5 siswa SMP, masing-masing sebesar Rp 60.000,- /siswa / per bulan, hingga total di Tahun 2014 : Rp 3,6 juta..

- Sementara dana hasil dari awal operasi PLTMH Cinta Mekar hingga Tahun 2014, yang dimanfaatkan untuk simpan pinjam anggota, modal simpan pinjam mencapai $\mathrm{R}$ 70 juta. Besar pinjaman tergantung kebutuhan / usahanya, ada yang besar p 1 juta; Rp 1,5 juta dan 2 juta. Adapun bunga pinjaman $2 \%$ / bulan. Bila dikarenakan penagihan dana ke PLN ini tak bisa kontinu per bulannya, maka dana bantuan berupa bea ke siswa pun kadang harus diberikan dalam rapel ( 3 bulan sekali).
- Masyarakat secara rutin menjaga sumber air Sungai Ciasem, sehingga debit air $1.1001 /$ detik ke PLTMH Cinta Mekar berlangsung secara kontinu, hal ini membuat out put energi listrik pun dapat kontinu, sebesar 100 $\mathrm{kW}$.

- Terjadi penurunan out put energi listrik dari PLTMH Cinta Mekar, berarti menurun pula energi listrik yang dijual ke PLN, sehingga akhirnya terjadi penurunan dana yang diperoleh Koperasi Mekar Sari. Hal ini tentu mengurangi upaya pemberdayaan masyarakat yang selama ini menjadi ikon andalan PLTMH Cinta Mekar.

- Masyarakat dalam arti warga setempat, mulai anak-anak hingga dewasa, sangat merasakan keberadaan PLTMH Cinta Mekar, sehingga hal ini membuat warga masyarakat turut menjaga keberlangsungannya. Selain pemberdayaan yang tersebut di atas tadi, Koperasi Mekar Sari pernah berperan serta dalam pembiayaan pembangunan infra struktur desa. Membantu 122 kepala keluaga untuk pengadaan listrik, dari semula rumah mereka tak tersambung listrik. Di samping 
itu, beberapa warga menjadi pengelola Koperasi Mekar Sari

\section{DAFTAR PUSTAKA}

1. Agra, I.B., 1989, Pokok pokok Metodologi Penelitian, Jurusan Teknik Kimia, Fakutas Teknik, UGM, Yogyakarta.

2. Arismunandar, A, Kuwahara, S., 2004, Teknik Tenaga Listrik, Pembangkitan dengan Tenaga Air, Pradnya Paramita, Jakarta.

3. Asdak C, 2004. Hidrologi dan Pengelolaan Daerah Aliran Sungai, Gadjah Mada University Press, Yogyakarta.

4. Banga, T.R. 1983. Hidraulics Fluid Mechanic \& Hydraulic Machines, Khanna Publ., New Delhi.

5. Beny Marbun, 2006, Prospek Tarif Dasar Listrik Ke Depan, Jakarta.

6. Cihanjuang Inti Teknik, 2004, Pedoman, Pengoperasian dan Pemeliharaan PLTM Turbin Propeler, Bandung.

7. Direktorat Pengembangan Enwergi, Petunjuk Teknik Konservasi Energi, Departemen Pertambangan dan Energi.

8. Djiteng Marsudi, 2005, Pembangkit Tenaga Listrik, Erlangga, Jakarta.

9. Dietzel, F., 1997, Turbin, Pompa dan Kompresor, Erlangga, Jakarta.

10. JICA, 2003, Panduan untuk Membangun Pembangkit Listrik Mikrohidro, NIPPON KOEI co. LTD, Jepang.

11. Maryono, A. Muth, W. Eisenhauer, N., 2001. Hidrolika Terapan, Pradnya Paramita, Jakarta.

12. Maryono, A. 2002. Eko-Hidraulik Pengelolaan Sungai, Magister Sistem Teknik FT UGM, Yogyakarta. 